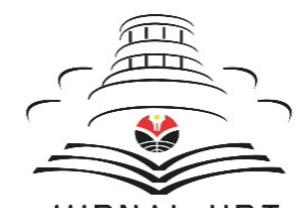

INDONESIAN JOURNAL OF APPLIED LINGUISTICS

Vol. 10 No. 3, January 2021, pp. 687-696

Available online at:
https://ejournal.upi.edu/index.php/IJAL/article/view/31755
https://doi.org/10.17509/ijal_v10i3.31755

JURNAL UPI

https://doi.org/10.17509/ijal.v10i3.31755

\title{
Redefining language and literature learning in the transformation era
}

\author{
Maman Suryaman, Wiyatmi, Setyawan Pujiono, and Ary Kristiyani \\ Department of Indonesian Language and Literature Education, Faculty of Languages and Arts, \\ Yogyakarta State University, Yogyakarta, Indonesia
}

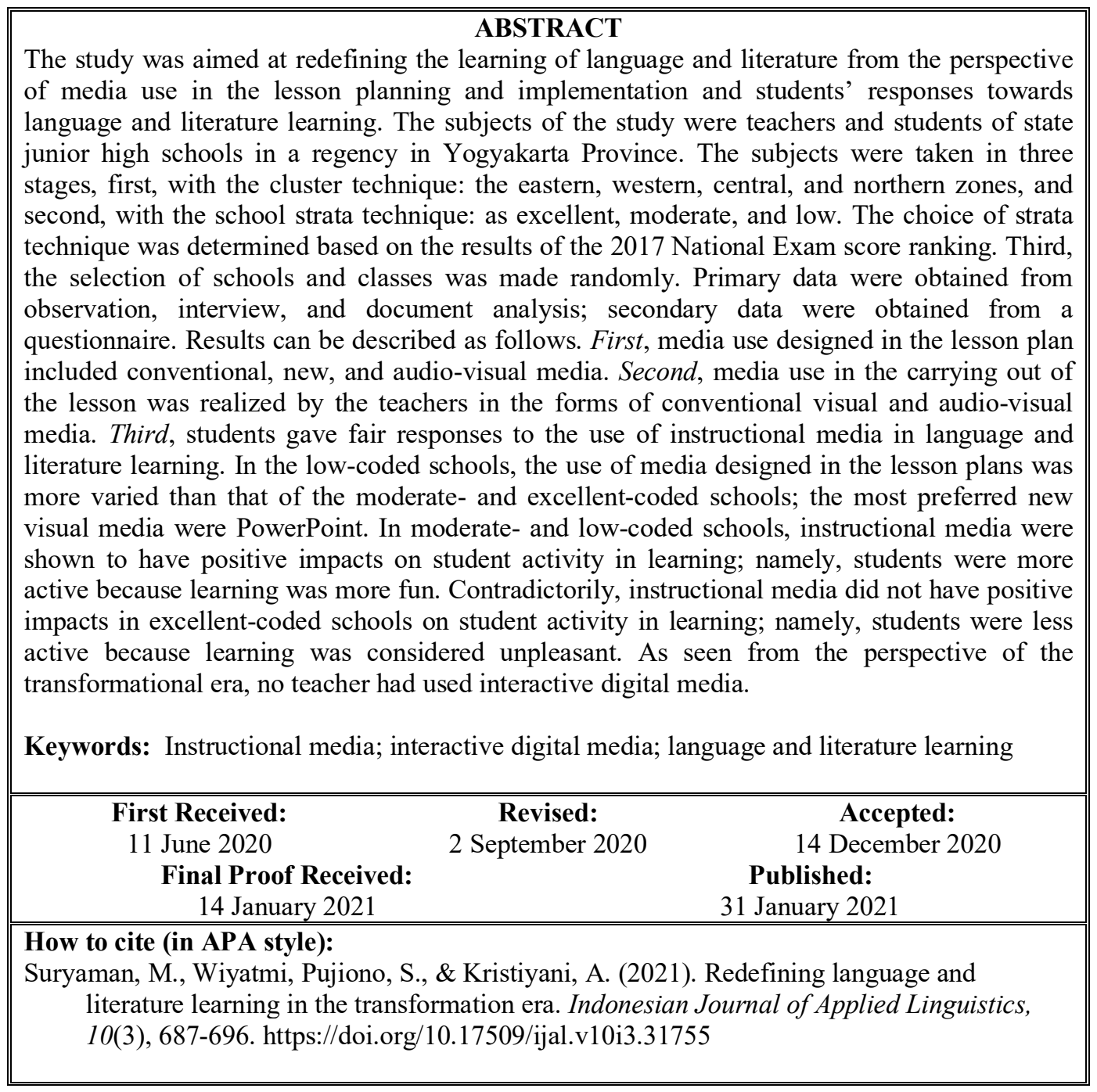

\section{INTRODUCTION}

It is mutually agreed that language and literature learning possess a strategic role in producing students' accomplishments in reading habits which become the basis for them to learn other subjects (Noor, 2011). Through language and literature learning, students' competencies are built in their reading, writing, speaking, listening, and viewing. These five competencies can be used by the students to develop their other competencies such as logic- mathematic and aesthetic (Mahsun, 2014). This strategic role can be realized once the components in the instructional processes are managed well. Conventionally, there are seven main instructional components of students, teacher, instructional objectives, content materials, method, media, and evaluation (Slameto, 2010). These seven components are interrelated and inseparable. The present discussion is concerned with the components of instructional media.

\footnotetext{
* Corresponding Author

Email: maman_suryaman@uny.ac.id
} 
Some of the terms used for instructional media are media education (Fedorov, 2008; Loicq, 2014), instructional media (Adegbija \& Fakomogbon, 2012; Brigss, 1997), learning media (Kozma, 1991), and multimedia learning (Mayer, 2005). Fedorov (2008) and Loicq (2014) define media education as deals with communication media and include the printed word and graphics, the sound, the still as well as the moving image, delivered on any kind of technology. Media education is a process through which students are able to critically understand the nature, techniques, impact, and issues of media messages (Fedorov, 2008; Loicq, 2014). Brigss (1997) defines instructional media as physical means which are used to send messages to the students and stimulate them to learn. According to Adegbija and Fakomogbon (2012), the instructional media are the human and non-human devices, materials, or methodologies used by the teachers to overcome all learning problems. It means that the instructional media is the key to transfer the knowledge from the teacher to the students effectively. Kozma (1991) defines learning media as a technology, symbol system, and processing capabilities. Mayer (2005) defines multimedia learning as building mental representation from words and pictures. The words can be spoken or written, and the pictures can be any form of graphical imagery including illustrations, photos, animation, or videos. In this article, the term used is instructional media.

Based on the definitions put forward by experts, it can be concluded that instructional media is a learning communication tool using technology, symbol systems, and processing capabilities in the form of words or images to stimulate students to learn so that positive mental representations are formed in order to overcome various learning problems. There are several types of instructional media: realia, pictures, coursebooks, boards, OHP, flipcharts, and computer based-technology (Harmer, 2007). Realia media for language learning are objects and teaching aids that are authentic and cannot be used for learning with a function as an introduction to the concept of material to facilitate and improve understanding (Harmer, 2007; Nunan, 1999). A picture is a graphic medium but not a photo-graphic or two-dimensional material which is designed as an intermediary for messages and information (Harmer, 2007). What is included in the picture media are graphics, charts, the pictures themselves, and cartoons. Pictures are media for training, communication, and understanding purposes. Coursebooks are media in the form of printed objects which contain materials, exercises, and assignments as new teachers in learning (Harmer, 2007; Onansanya, 2004). The board media is a learning medium in the form of a blackboard in the classroom (Harmer, 2007). The benefits of the board in language learning in the classroom are in the framework of students in learning, student understanding, easy to use, supports paper, does not require technical support, and is efficient. Boards can be used for a variety of purposes, such as notebooks, explanation aids, photo frames, general workbooks, game boards, and noticeboards. The Overhead Projector serves as an intermediary for students to see materials in front of the class and helps teachers present the materials in full. Flipchart is a medium that contains big sheets of paper (Harmer, 2007) which is widely used in discussions to fill in the points being discussed. According to Harmer (2007), computer-based presentation technology consists of hardware and software. Hardware is in the form of computers and LCDs. This instructional media combines both audio and visual materials.

Methods of media education may be classified according to the mode of presentation: aural (lecture, conversation, explanation, discussion), demonstration (illustration, audio, visual or audiovisual), and practical (various media activities), and the level of the cognitive activity: explanatory demonstrative (communication of certain information about media, its perception and simulation; reproductive (exercises, tasks that help students master the technique of their solution; problem (the problem of analysis of certain situations or text targeted (creative quest activities) (Fedorov, 2008). Bates (2019) classifies media types into text, graphics, audio, video, and computing. The text includes textbooks, novels, and poems; graphics include diagrams, photographs, drawings, posters, and graffiti; audio includes sounds and speech; videos include television programs, YouTube clips, and talking heads; and computing which includes animation, simulations, online discussion forums, and virtual worlds. In general, it can be concluded that the types of media include audio, visual, audio-visual, and computer media.

Various research shows the role of media in the effectiveness of learning. Mateer et al. (2018) also stated that the use of media in teaching English would help students to relate the concepts to the context more easily. The functions of using instructional media in the teaching and learning process, which were investigated in this study are in line with the result found by Fatimah (2017), Mohan (2013), and Rokhayani and Utari (2014). The instructional media intends to assist teachers in presenting the materials to their students (Gan et al., 2015). Instructional media have an important role in building effective learning. Appropriately chosen media can improve students' learning achievements. A study by Yu-Feng Land et al. (2011) provides evidence for this claim. Findings of this study show that well-designed media have a positive and significant impact on the success of writing, elevation of motivation, and degrees of fun and anxiety during the learning of writing. 
These findings strengthen the views that instructional media have the functions of stimulating students' thoughts, feelings, attention, and intention for learning to occur. Ibrahim et al. (2014) shows that Web 2.0-based media are capable of elevating students' abilities to adopt new learning behaviours, cooperative practices, interactive involvement, and social responsibilities in line with their virtual community realities as well as to acquire strong positive perceptions and experiences of the Web 2.0-based instructional media towards meaningful informal English learning. This means the higher the use of instructional media, the more effective the process and product of instruction, including those in language and literature. According to Corson (2008), media in language learning plays a strategic role in creating spaces for students to better understand language concepts more quickly so that they are ready to learn to write, speak, read, and listen. According to Mayer (2012), multimedia contains messages between language and images that will encourage learning to be more effective.

Research related to the use of media in learning is important given the significant impact of media on learning effectiveness (Corson, 2008; Fatimah, 2017; Gan et al., 2015; Ibrahim et al. 2014; Mateer et al., 2018; Mayer, 2012; Mohan, 2013; Rokhayani \& Utari, 2014; Yu-Feng Land et al., 2011). Moreover, for over 20 years, the Corporation for Public Broadcasting (CPB) conducted surveys of classroom uses of television and video that revealed increased use of satisfaction with video in the classroom. In the most recent surveys, 92\% of teachers said that using TV and video helped them teach more effectively, and $88 \%$ said that it enabled them to be more creative in the classroom (Cruse, 2007). In general, CPB (Cruse, 2007) concludes that the use of $\mathrm{TV}$ dan video reinforces reading and lecture materials, aids in the development of a common base of knowledge among students, enhances student comprehension and discussion, provides greater accommodation of diverse learning style, increases student motivation and enthusiasm, promotes teacher effectiveness (Cruse, 2007).

These findings indicate a high variation in the use of media, including information technologybased learning media. However, similar research has not been carried out in many schools in Indonesia. Until now there has been no map of the results of research on the use of information technology-based learning media. Therefore, research to map the use of instructional media in schools in Indonesia is important. The research problem of the present study is therefore related to questions concerning the learning of language and literature viewed from the media component of the instructional process. More specifically, three research questions are asked: what is media use like in the planning of the language and literature learning; what is media use like in the carrying-out of the language and literature instruction; and what are students' responses on the language and literature learning process?

\section{METHOD \\ Research Approach}

The study used a mixed-method research design. The use of the descriptive qualitative and quantitative approaches in combination was intended to obtain research data that were more comprehensive, valid, reliable, and objective. The qualitative method was used to collect primary data through observation, field note-taking, interview, and documentation. The quantitative method was used to elicit students' responses through a questionnaire for secondary data. This research approach was intended to give data that were thorough and accurate concerning the subject and object of the study.

\section{Research Subjects}

The subjects of the study were 15 Indonesian language teachers and 478 students of the $7^{\text {th }}$ and $8^{\text {th }}$ grades of State Junior High Schools in Sleman Regency (henceforth: SSJHS). By purposive random sampling, the research participants were determined in three phases. First, in clusters or zones, the research location was divided into east, west, middle, and north (Dinas Pendidikan Sleman, 2017). Second, in school stratas, the schools were categorized as excellent, moderate, and low based on the previous year of the national examination (Dinas Pendidikan Sleman, 2017). Third, the choice of schools and classes was done randomly. The research subject of the study was the use of instructional media in the learning of language and literature in the $7^{\text {th }}$ and $8^{\text {th }}$ grades of Junior High School between February and May 2018. The following is a summary of school samples. There are three samples of excellent schools (ES) coded as S1, S3, and S5; three samples of moderate schools (MS) coded as S4, S6, and S7; and two samples of lower schools (LS), coded as S2 and S8.

\section{Data Collection Technique and Instrument}

Data were collected through non-participative observation in the form of field notes, interviews, document analyses, and student questionnaires. The researchers, as the human instruments, determined the research focus, selected informants as data sources, collected and appraised data quality, conducted data analyses, gave interpretation to the analysis results, and made conclusions. The research instruments were observation sheets, interview guides, document analysis guides, and questionnaires. These instruments were used to elicit information concerning the use of instructional media in the learning of Indonesian at Junior High 
Schools, specifically on text learning of non-fiction, drama, and fables.

The observation sheet contains students' activities, teachers' activities, and kinds of media used in the learning process. The observation guidelines for the use of learning media contains characteristics and strata of the school, school code, observation time, type and completeness of the materials, the suitability of the content of the materials with basic competencies, the type of media, and the suitability of the use of media in planning with the implementation of learning. Field notes were used to record what happened in the teaching-learning process between the teacher and students in the class. Field notes contained the instructional activities during the opening phase, main phase, and closing phase. The interview guide contains open-ended questions to the research respondents. It was related to the designing of the instructional media and the use of the media in the instructional activities. The description of the interview focus includes the creation of media comprising media creators, how to create media, and tools for making media as well as types of media including visual media, audio media, audio-visual media, and multimedia.

The questionnaire was used to elicit students' responses on the use of the instructional media by the teacher in class and to validate results of observation, interview, and document analysis. Before being administered to the students, the questionnaire was validated by the Indonesian teachers of the $7^{\text {th }}$ and $8^{\text {th }}$ grades in each school. Scoring used the Guttman scale with yes and no response options. In completing the questionnaire, students filled out their identities and checked $(\sqrt{ })$ their answer on the response sheet. The specification of the questions in the questionnaire covers three aspects, namely the use of learning media in 11 items, 7 types of learning media, and the impact of using learning media in 7 items. The total number of items in the questionnaire is 25 .

\section{Data Analysis}

Research data were qualitative and quantitative. Qualitative data were presented to describe, provide evidence, deepen, and extend data description through discourse expressions. Raw data were organized and managed through the steps of: (a) data reduction; (b) data presentation; and (c) data interpretation (Miles \& Hubermen, 1992). Quantitative data were processed to find score means, percentages, and standard deviation measures for each aspect. In the computing process, the response yes and no in the questionnaire were scored 1 and 0 . Statistical results were grouped into the categories of high, fair, and low.

The categorization of each score shows the tendency of the research variable. There are three categories, namely high, fair, and low. The categorization is determined by the obtained scores of the ideal mean and standard deviation. The level of variable tendency is divided into three categories, namely good, moderate, and insufficient. Based on the results of calculating the ideal mean and ideal standard deviation for students' responses to the use of media in the non-fiction text learning process, the average score ranges from 78,45-100 (good), 63,9778,44 (sufficient), and 0-65, 31 (less). The results of calculating the ideal mean and ideal standard deviation for students' responses to the use of media in the learning process of fable text and drama obtained an average score range of 82-100 (good), 72.2-81.9 (sufficient), and 0-76,18 (less).

\section{FINDING S AND DISCUSSION}

Research results are presented in tables. Data of the document analyses, observation, interview, and questionnaires are grouped into planning, implementing, and students' responses to teacher's activities of the language and literature instructional processes, especially non-fiction, drama, and fable texts.

This part presents the description of the use of instructional media in the planning and implementing phases and students' responses towards the language and literature learning process. Data on media use in the learning process cover media in the planning phase and their kinds; media in the implementing phase and their kinds; and students' responses on the instructional process. Each coverage is explained following the research questions.

\section{Media Use in the Planning}

Based on the document analyses concerning the planning of media use in non-fiction texts learning in the three stratas of excellent, moderate, and low schools, findings can be shown as follows. First, among the eight schools, seven teachers included media in their lesson plans, while one teacher in S1) did not. Second, the kinds of media mentioned in the lesson plans were conventional visual media, new visual media, and audio-visual media. Third, in schools with a low category (LS), new visual media were planned using PowerPoints (PPt) by S8, whiteboard conventional media (WhB) and workbook (WB) were planned by S4, while S2 included audio-visual media in instructional videos (IV). Fourth, in the moderate-strata schools (MS), the planned media were new visual media using PowerPoint (PPt) in S6 and visual conventional media using Whiteboard and Workbook in S7. Fifth, in schools with a high category (ES), the planned media were new visual media in PPt (S3 and S5), while in S1, no media were found in the lesson plans. This contrast becomes interesting because audio-visual media were only found in LS. Instructional media that were most attractive to 
teachers were PPt (in four schools) and the second ones were whiteboard and workbook (in two schools). It could be concluded that in LS, planned instructional media are more varied than they are in MS and ES, and that PPt becomes the new visual media most preferred by the teachers.

Meanwhile, for drama and fable text learning, the following results of the lesson plan for the three school stratas can be described as follows. First, all schools include media for text learning in most of their lesson plans. In this case, in seven lesson plans, teachers designed the use of visual-conventional media, and in the others (seven out of 15 class sessions), they did not include media. Similarly, during the designing phase, not all lesson plans mentioned the use of audio-visual media. The use of audio-visual IV media was mentioned in six class sessions but was not found in the remaining nine meetings. Second, the media mentioned in the lesson plans were conventional video in $\mathrm{WhB}$ and audiovisual media in IV. One media that was not mentioned in the lesson plans was the new visual media type. This is interesting that the new media did not appear in any of the lesson plans, while the audio-visual media in IV, either in LS, MS, or ES, was mentioned there. This means that audio-visual IV media were more preferred by all teachers than the new visual media. There was a striking difference in the use of instructional media in the lesson plans for the media types. For texts of nonfiction, the most preferred media by the teachers were the PPt, while for drama and fable texts, the most preferred media were the instructional video.

\section{Media Use in the Implementation}

Based on the results of the research observations, the description of the media use in the carrying-out of the learning processes in the eight schools can be reported as follows. First, seven schools carried out the teaching-learning processes using instructional media, whereas S1 did not use any media. Second, the media used were of the categories of conventional visual, new visual, and audio-visual media. Conventional visual media were whiteboard and workbook, new visual media were the PPt, and audio-visual media were instructional videos; conventional visual media were conducted in S4 and $\mathrm{S} 7$; new visual media were used in S8, S6, S3, and S5; and audio visual-instructional videos were used in S8. The use of the new visual media was in the form of PPt, in line with what was designed in the lesson plans, while conventional visual media were consistently used in S4 schools. Audio-visual media in the form of instructional videos were not used consistently; the instructional video media were mentioned in the lesson plans in S2 but the teachers did not implement it in the instructional processes. Conversely, S8 teachers did not design it in the planning phase, but they did use the instructional video media in the learning processes. This happened in the LS school strata (S8). The use of these audio-visual media was aided by classroom facilities such as sound sets and LCD projectors. Teachers also have laptop sets to play videos. The classroom is therefore equipped with primary and secondary tools for the teachers to operate the instructional media. In summary, there was a discrepancy in the use of instructional media between what was designed in the lesson plans and what was implemented in the classroom. Some teachers did not use instructional media in the classroom and the media used in the teachinglearning processes were widely varied.

\section{Students' Responses towards the Instructional Processes of Learning}

Based on the analysis results of the student questionnaires, students' responses on the use of instructional media in the non-fiction text learning can be reported as follows. First, in schools with the ES strata code, the obtained score was 75.65 (Low). Second, in schools with the MS strata code, the obtained score was 76.84 (Fair). Third, in schools with the LS strata code, the obtained score was 82.90 (High). As for students' responses on the use of instructional media in drama and fable text learning, scores can be reported as follows. First, in schools with the ES strata code, the obtained mean score was 70 (Fair). Second, in the MS strata schools, the obtained mean score was 77.24 (Fair). Third, in the LS strata schools, the obtained score was 71.34 (Fair). In general, students' responses towards media use in the language and literature instructional processes can be categorized as "fair". Deliberation of media use in the planning and implementing stages of the instructional processes and its impacts on students is viewed from the related research findings. Discussion on the research results is focused on the research questions: what is media use like in the instructional planning; what is media use like in the carrying-out of the instructional process; and what are students' responses on the use of media in the language and literature learning process?

\section{Media Use in the Planning}

The discussion of learning becomes an interesting topic whenever it is related to its effectiveness. One way to appraise effectiveness is by looking at the interaction patterns between the students and teacher and among students. It is from the use of media that such interaction can be viewed. The first thing is to look at how media use is designed in the planning stage. As found in the research results, the use of instructional media in the planning stage is not optimal. The media mentioned in the lesson plans are still general, although they have adequate varieties such as workbooks, whiteboards, and PowerPoints. Furthermore, in the implementation phase, the planned media have not become 
references for use. Teachers tend to shift to using other media. The shift of media in the implementation phases does not consider recentness. Teachers tend to resource to conventional media. They do not see the possibility of shifting to media that are varied, rich, and interactive in the perspectives of the potentials of development of informational technology. For example, no media are attempted that will use simulation, the Website, non-content videos, pure animation, motion graphics, augmented reality, etc. A question can be raised concerning this problem. The following interview notes can give possible answers.

Yeah (we) have tried (to use such media, res.) to be consistent between media and in the lesson plan and media in the classroom. But here's the problem. At the beginning of the school year, I've been assigned to teach Year VIII. But, why on earth was there suddenly a pensioner called in to teach Year VII? Then, automatically, I have to write the lesson plans.

Some other reasons are related to teachers' competencies and media references that are considered inadequate. Three of the eight researchsubject teachers acknowledge that they have not attended training in developing learning media for Indonesian lessons, including digital-based media. Concerning this matter, these teachers express their expectation to receive training in media development. The following is a transcript of one of the interviews with teachers who have joined such training.

Training in instructional media development can extend perspectives, generate ideas, and provide opportunities to learn new things. Such training can become a forum of discussion among teachers. We hope that young teachers and teacher candidates have high motivation to develop and use instructional media. As one of the teachers who have received training, I feel that training in media development enriches teachers' experiences in making and using learning media.

A study by Nurhidayati (2011, p. 94) shows that planning of media use has a great impact on students in their listening activities. Students' enthusiasm in their listening activities is related to the consistency of the learning design with the learning needs, learning objectives, and learning conditions. The quality of the students' activities can be seen from the emergence of the indicators in the lesson plans.

What is common between Nurhidayati's study and the present study is the recommendation that good lesson planning helps in the success of learning. In this context, good planning in the use of instructional media has a positive impact on the process and product of learning. It is a fact, however, that teachers have not been optimal in designing media to be used in the language and literature learning activities. Some of the causing factors can be as follows. First, the lesson plans to be used in class have not been the products of the teachers' work. They are developed by the Indonesian Language Teachers' Forum (a non-profit organization of Indonesian language teachers in this profession). Second, the media designed in the lesson planning is not media prepared by the teacher but is prepared by the teacher association so that teachers do not feel they have to apply it in learning.

It has been stated by experts that appropriate media use in the lesson plan and in the classroom can improve students' learning motivation. That use of learning resources -including instructional media- gives a positive impact on the students so that the learning process can be more effective, innovative, and fun (Herayanti et al., 2017).

The impact of planning that is not optimal is the appreciation of the low strata students towards the teaching-learning process developed by the teacher. It is even true that, in schools of the excellent and moderate stratas, the use of instructional media does impact significant contribution. It is found as a fact that students' responses towards the use of instructional media in the language and literature classes are low in some schools and fair in schools with excellent and moderate stratas.

Wati (2016) states the factors that influence the criteria for choosing instructional media include learning objectives, learners' characteristics, intended learning stimuli, background or environment conditions, and the extent of ranges to cover. In line with this, through observations and interviews, it is found that teachers use a variety of media to be suited to the learning conditions. The choice of media, however, has not considered up-todatedness which tends to be more interactive, such as media simulation, video, and augmented reality. The vast availability of interactive media accessible on the internet has not become a resource in the planning of the use of media in the learningteaching process.

An interesting finding is why PowerPoints are the most popular media among teachers. The teachers who were respondents were those who already owned and used laptops during the lesson. However, most of the teachers use their computer sets merely for presenting PowerPoints. The computer sets and their applications have not been used optimally for other media applications that are more attractive and interactive. The reason is that teachers have not had any training on media use and development. Besides, they do not have enough 
references on how to use interactive media in spite of the fact that this has become a daily consumption in society, including children. This is in line with what Arsyad (2011) emphasizes that one criterion for the choice of instructional media is the ability of the teachers in using the tools. Whatever the media is, teachers must be able to operate it in the learning process. The value and function of media depend on the teachers' abilities to operate them. The fact is that teachers only know the PPt; they are not familiar with other interactive media.

Teachers do acknowledge the usefulness of media use in the teaching and learning of language and literature. Without the use of media, the instructional process will not run as effectively. The following is a transcript of an interview with a teacher.

Teachers must fulfill students' needs and abilities in learning by selecting the appropriate instructional media. Good schools with active students need to provide media that can make the students interested in participating in learning activities. In a situation where teachers are not able to provide interesting media, students will tend to neglect the learning activities. This is also true for schools with low-level students. Lowlevel students need the motivation to learn so that teachers need to provide them with instructional media that will support them to learn.

This good awareness of teachers towards media use is, however, blocked by several obstacles. One of the obstacles is the fact that they have not had the opportunity to join training programs. Another one refers to the unavailability of references that will enable the teachers to educate themselves in developing interactive learning media.

\section{Media Use in the Implementation}

The findings related to the use of media in implementing language and literature learning can be summarized as follows. The use of both conventional and new media has positive impacts on students of the low-strata schools but less positive on students of the moderate and excellent-strata schools. The positive impacts on students of the low-strata schools are that the use of instructional media helps them to speed up critical thinking (comprehension, analysis, synthesis), raise and develop imagination, and stimulate interactive discussion.

Awareness of the importance of media use for instructional purposes has been felt by teachers and followed by the conduct of lesson planning. This, however, is not followed-up in the implementation phase because of obstacles as it has been described previously. Teachers are also of the same stances that, without the use of media, the learning of language and literature will not uphold concentration, raise and develop imagination, enhance students' interactive discussion, nor speed up students' critical thinking (comprehension, analysis, and synthesis). Without media, students will not flourish their enthusiasm to know more. This is in line with experts' judgments that instructional media used in the teaching-learning process have positive impacts on learning. As an example, Kemp and Dayton (1985) state that the advantages of using instructional media in the learning process can be seen in several aspects; among others: learners' positive attitudes, learning product quality, and learners' active participation. In the same tone, Ealy (2016) states that critical thinking skills can be stimulated by visual media; it is why instruction with visual media tends to be more effective (Turkoguz, 2012). Turkoguz (2012) even emphasizes Ealy's (2016) that instruction using visual media gives the teachers strong supports in digging up honesty, creating effective communication, and providing learning flexibility.

Another study that is relevant to the present findings is that of Sunarti et al. (2016). Their findings show that there is a difference in the learning motivation between students who are taught using games and visual media and those who are taught using conventional media. In another study, Rahayu and Riska (2018) find that vocabulary learning is often boring because it is done merely by copying and memorizing. After being subjected to an experiment using games as media, the students experience a significant change in the form of positive responses. In another study, it is shown that language learning using Facebook can increase learners' self-confidence and motivation (Kabilan \& Zahar, 2016). Still from another study, it is shown that good use of instructional media contributes significantly to the improvement of learners' motivation and teachers' and learners' active participation (Nugrahani, 2017) and (Sunarti, 2016). Meanwhile, the use of effective media can be appraised by its impacts whether or not it can differentiate superior schools from inferior ones and effective teachers from less effective ones (Oyedele et al., 2013).

Teachers have used the computer as an instructional idea in the learning process; however, it consists mostly of displaying PowerPoints on the screen. Interactive computer use as instructional media is not done yet. According to media experts, computer-based learning can be divided into two groups: computer-based training (CBT) and webbased training (WBT). The first model uses computer appliances with a CD-ROM with built-in video contents, animations, graphics, etc. (Horton, 2000). This model is quite strategic for use by the teachers and students in the classroom for independent and group works. The second model, 
suggested by Rossett (2002), is closer to the $e$ learning mode. In this mode, the learning and teaching processes are carried out by using the Internet. The students and teacher can access instructional contents extensively from the Internet. They can compare the many sets of instructional materials through critical reading. Web-based learning consists of the provision and development of instructional materials by way of multimedia and computer to support learning activities that are not bound by space and time. Websites take an important part in web-based learning and are one of the examples of the importance of the Web in education. The Internet plays a critical role in education such as providing a vast bulk of information, speeding up communication, providing space and environment for creativities, and presenting instruction (Nachmias \& Tuvi, 2001). In this case, there is a lot of opportunities for communication between teacher and students and among students. There is also a wide possibility for on-line communities to share information and together develop their knowledge. There are at least five dimensions or criteria in good web uses for instruction; namely descriptive dimension, pedagogic dimension, representational dimension, communicative dimension, and content dimension.

From previous research results, there is a firm standpoint that the use of instructional media in language and literature learning is very important. The present study gives a note however that the use of media in the learning-teaching process is not yet optimal. The instructional media that are planned and implemented by teachers have not been characterized by variety and interactiveness that mark the demand of time (digital transformational era). This can be seen from the students' responses to the language and literature learning that cannot be categorized as satisfying.

\section{Student Responses to the Instructional Processes of Learning}

The fair score obtained for students' responses towards the use of instructional media in the language and literature learning shows that teachers have not exercised optimal use of the media. This means that the impacts of the use of the instructional media have not come to a straight correlation with the varieties of media that the teachers select. It is even shown that the more excellent the school strata are, the lower the responses are. On the other hand, the use of instructional media has positive impacts in low-strata schools and less positive in excellentstrata schools. This, however, happens only for nonfiction text learning. As for drama and fable text learning, impacts are categorized as "fair" for all school stratas. It can be inferred that present-day learning that is planned and implemented by teachers must consider the use of interactive media, either in the format of computer-based training or web-based training. This is supported by Fitriyana et al.'s (2020) study by showing that there is a significant difference in students' achievement and self-confidence between android-game based instruction and conventionally-mixed instruction. Students who are taught by android-game instruction have higher scores in achievement and self-efficacy than students from the other groups.

The most recent development in the use of the latest instructional media must be responded to positively by practitioners, observers, and policymakers. The two computer-based media use models have not been responded to well by teachers. On the contrary, teachers use out-of-date media. This must be given due attention by the personnel. As previously mentioned, teachers' experiences in the use of instructional media have not been adequate. It must be understood that the inadequate use of interactive media in the instructional processes is not merely the weaknesses on the part of the teachers; review and revision must also be subjected to the wider education system. Efforts in facilitating teachers to join training programs and attend seminar forums must be realized by the Government, the school, and the individual teacher.

\section{CONCLUSION}

Based on the findings and discussion of the study, the conclusion can be put forwards as follows. First, one of the effective measures of language and literature learning today is the use of digital multimedia so that learning can help teachers explain material and facilitate students to find it easy to understand dissertation material with motivation, encouragement, and challenges to create creative, critical thinking skills, and fun. Second, the use of digital multimedia in language and literature learning has been empirically tested which has the effect of being able to arouse student learning motivation and learning to be more interesting. Digital multimedia also eases the burden on teachers in terms of time management because it becomes more efficient, students do not have to be burdened by the teacher to write teaching materials on the whiteboard or teaching materials can be accessed by students digitally compared to the use of conventional media. Third, redefinition is focused on strengthening the program of the Ministry of Education and Culture of the Republic of Indonesia related to the digitalization of schools under the name of the Rumah Belajar portal. If language and literature learning in schools has directed digital media-based learning, the Rumah Belajar Portal will be easily accessible to students and teachers. Fourth, redefinition is also directed at increasing teacher competence. Programmatically, teachers must receive facilitation for training and debriefing in mastering digital media for language and literature learning. Fifth, the redefinition of language and 
literature learning must be supported by adequate facilities and infrastructure for the development and implementation of digital media-based learning.

\section{ACKNOWLEDGEMENTS}

This article is written from the results of a research study funded by the DIPA of the Faculty of Languages and Arts, Yogyakarta State University, in 2018. We acknowledge our thankfulness to our reviewers Prof. Suminto A. Sayuti and Prof. Burhan Nurgiyantoro (Professor of Yogyakarta State University).

\section{REFERENCES}

Adegbija, M. V., \& Fakomogbon, M. A. (2012). Instructional media in teaching and learning: A nigerian perspective. Global Media Journal, 6(2), 216-230. https://doi.org/10.5789/6-2-114

Arsyad, A. (2011). Media pembelajaran. PT Raja Grafindo Persada.

Bates, A.W. T. (2019). Teaching in a digital age: Guidelines for designing teaching and learning. Tony Bates Associates Ltd.

Brigss, L. J. (Ed). (1997). Instructional design: Principles and applications. Englewood Cliffs.

Corson, D. (2008). Learning in language other than mother tongue in IB programmes. Cardiff Gate.

Cruse, E. (2006). Using educational video in the classroom: Theory, research and practice. https://safarimontage.com.

Dinas Pendidikan Kabupaten Sleman. (2017). Data pokok pendidikan tahun 2017. http://backbonedapodik.slemankab.go.id/ backbone/index.php.

Ealy, J. B. (2016). Visualization of kinetics: Stimulating higher-order thinking via visualization. Journal of Chemical Education, 3(2), 394. https://doi.org/10.1021/acs.jchemed.5b00 215.

Fatimah, A. S. (2017). Teaching in 21st century: Students-teachers' perception of technology use in the classroom. Journal of Linguistic and English Teaching, 2(2). https://doi.org/10.24903/sj.v2i2.132

Fedorov, A. (2008). On media education. ICOS UNESCO IFAP (Russia).

Fitriyana, N., Wiyarsi, A., Ikhsan, J., \& Sugiyarto, K. H. (2020). Android-basedgame and blended learning in chemistry: Effect on students' self-effficacy and achievement. Cakrawala Pendidikan: Jurnal Ilmiah Pendidikan, 39(3), 507521. https://doi.org/10.15390/eb.2014.1858

Gan, B., Menkhoff, T., \& Smith, R. (2015). Enhancing students' learning process through interactive digital media: New opportunities for collaborative learning. Computers in Human Behavior, 51, 652663. https://doi.org/10.1016/j.chb.2014.12.048

Harmer, J. (2007). The practice of English language teaching (4th ed.). Pearson Education.

Herayanti, L., Fuadunnazmi, M., \& Habibi. (2017). Pengembangan media pembelajaran berbasis moodle pada matakuliah fisika dasar. Cakrawala Pendidikan, 36(2), 210-219. https://doi.org/10.21831/cp.v36i2.13077.

Horton, W. (2000). Designing web based training. John Wiley \& Son Inc.

Ibrahim, Ch. W. I. R. Ch. W., Prain, V., \& Collet, P. (2014). Perceived learning strategies of Malaysian university students in web 2.0-based English as a second language informal learning. GEMA Online $\circledR$ Journal of Language Studies, 14(1), 29-42. https://doi.org/10.17576/GEMA-20141401-03.

Kabilan, M., H., \& Zahar, T., Z., M., E. (2016). Enhancing student's vocabulary knowledge using the Facebook environment. Indonesian Journal of Applied Linguistics, 5(2), 217-230. https://doi.org/10.17509/ijal.v5i2.1346

Kemp, J. E., \& Dayton, D. K. (1985). Planning and producing instructional media. Harper \& Row Publishers.

Kozma, R. B. (1991). Learning with media. Review of Educational Research, 61(2), 179-211. http://links.jstor.org/sici?sici=003465439o281991229o29619o3A293C1799 3ALWM9 3E2.0.COC 3B2-D.

Loicq, M. (2014). Media and information literacy in the digital age. An example on exploring plurasim. In M. Stocchetti (Ed.), Media and education in the digital age. Peter Lang.

Mahsun. (2014). Teks dalam pembelajaran bahasa indonesia kurikulum 2013. Raja Grafindo Persada.

Mateer, G. D., Ghent, L. S., Porter, T., \& Purdom, R. (2018). Using media to enhance teaching and learning. Action the SERC Portal for Educators. https://serc.carleton.edu/sp/library/media/ index.html.

Mayer, R. E. (2005). The Cambridge handbook of multimedia learning. Cambridge University Press. https://doi.org/10.1017/CBO9780511816 819.002. 
Mayer, R. E. (2012). Cognitive theory of multimedia learning. University of California.

Miles, M. B., \& Huberman, A.M. (1992). Qualitative data analysis: A sourcebook of new method (Rohidi, T. R., Trans.). Penerbit Universitas Indonesia (UIPRESS).

Mohan, S. (2013). Instructional media for effective language teaching. International Journal of Humanities, Arts, Medicine and Science, 1(3), 81-84.

Nachmias, R., \& Tuvi, I. (2001). Taxonomy of scientifically oriented educational websites. Journal of Science Education and Technology, 10, 93-104. https://doi.org/10.1023/A:101662481191 2.

Noor, N. M. (2011). Reading habits and preferences of EFL post graduate: A case study. Indonesian Journal of Applied Linguistic, 1(1), 1-9. https://doi.org/10.17509/ijal.v1i1.95

Nugrahani, F. (2017). The development of film based literary materials which support character education. Cakrawala Pendidikan, 36(3), 472-486. https://journal.uny.ac.id/index.php/cp/arti cle/view/14219

Nunan, D. (1999). Second language teaching and learning. Heinle \& Heinle.

Nurhidayati. (2011). Pembelajaran menyimak apresiatif cerita pendek dengan strategi belajar kooperatif. LITERA, 10(1), 94. https://doi.org/10.21831/ltr.v10i1.1175

Onansanya, S. A. (2004). Selection and utilization of instructional media for effective practice teaching. Institute Journal of Studies in Education, 2(1), 127-133.

Oyedele, S., Rwambiwa, J., \& Mamvuto, A. (2013). Using educational media and technology in teaching and learning processes: A case of trainee teachers at Africa university. Academic Research International Journal, 4(1), 292-300. http://www.savap.org.pk/journals/ARInt./ Vol.4(1)/2013(4.1-30).pdf

Rahayu, W. A., \& Riska, S. Y. (2018). Pengembangan media pembelajaran game kosakata Bahasa Inggris. Jurnal Ilmiyah Pendidikan, 37(1), 85-96.

Rokhayani, A., \& Utari, A. R. P (2014). The use of comic strips as an English teaching media for Junior High School students. Language Circle Journal of Language and Literature, 8(2), 143149.

https://journal.unnes.ac.id/nju/index.php/LC/ar ticle/view/3018
Rossett, A. (2002). The ASTD e-learning handbook. McGraw-Hill Companies Inc.

Sunarti, Rahmawati, S., \& Wardani, S. (2016). Pengembangan game petualangan "Si Bolang" sebagai media pembelajaran tematik untuk meningkatkan motivasi dan prestasi belajar siswa kelas V sekolah dasar. Cakrawala Pendidikan, 35(1), 5868. https://doi.org/10.21831/cp.v1i1.8365.

Slameto. (2010). Belajar dan faktor-faktor yang mempengaruhinya. Rineka Cipta.

Turkoguz, S. (2012). Learn to teach chemistry using visual media tools. Journal of Chemistry, Education, Resercah, and Practice, 13(4), 389-400. https://doi.org/10.1039/C2RP90013K.

Wati, E. R. (2016). Ragam media pembelajaran. Kota Pena.

Yu-Feng Land, Chun-Ling, \& Hung-Ju Hsu. (2011). Effect of guided writing strategies on student writing attitudes based on media richness theory. The Turkish Online Journal of Educational Technology. 10(4), 149-152. https://eric.ed.gov/?id=EJ946620 